\title{
QUALITY OF WOOD AND PULP FROM A CLONE OF Eucalyptus grandis PLANTED AT THREE LOCATIONS
}

\author{
Cláudio Angeli Sansígolo ${ }^{1}$, Éder da Silva Ramos²
}

(received: October 18, 2009; accepted: November 30, 2010)

\begin{abstract}
Eucalyptus grandis is one of the most popular species to use as raw material for pulp production in Brazil, as it provides excellent pulping, bleaching and papermaking results. The main objective of this study is to examine the quality of wood and pulp from a clone of Eucalyptus grandis, at age 4 years approximately, planted in three different soils, two of which being low fertility and one being a superior fertility soil, and their reflections on wood quality and pulping results. Chemical analyses of the soils followed guidelines developed by Raij et al. (2001), while physical and chemical properties of the wood followed ABTCP, TAPPI and ABNT standards. Chemical analyses of the soils pointed to lower fertility in Fazenda Limeira and Fazenda Tapera Queimada as opposed to higher fertility in Fazenda Mendes União. Results revealed stronger tendencies for the stand grown in the less fertile soils (Fazenda Limeira and Fazenda Tapera Queimada) in comparison to the stand grown in more fertile soil (Fazenda Mendes União) as to: higher wood and bark basic density, lower height and dry matter content, higher bark content, lower extractives content and higher holocellulose content, higher total and screened yields from pulping, lower specific wood consumption/t of pulp, and higher tear and tensile indices at low refining levels.
\end{abstract}

Key words: Soil fertility, wood properties, Kraft pulp.

\section{QUALIDADE DA MADEIRA E DA CELULOSE DE UM CLONE DE Eucalyptus grandis PLANTADO EM TRÊS LOCAIS}

RESUMO: O Eucalyptus grandis é uma das espécies que mais se destacam como matéria prima para produção de polpa no Brasil, pois oferece excelentes resultados da polpação, branqueamento e fabricação de papel. Objetivou-se, com o presente trabalho, estudar a qualidade da madeira e da celulose de um clone de Eucalyptus grandis, com aproximadamente 4 anos, plantado em três solos diferentes, sendo dois solos de baixa fertilidade e um solo de fertilidade superior, e seus reflexos na qualidade da madeira e resultados da polpação. As análises químicas dos solos foram realizadas segundo as normas preconizadas por Raij et al. (2001) $e$ as caracterizações físicas e químicas da madeira foram realizadas de acordo com as normas da ABTCP, TAPPI e ABNT. As análises químicas dos solos mostraram menores fertilidades para as Fazendas Limeira e Tapera Queimada e maior fertilidade para a Fazenda Mendes União. Os resultados mostraram fortes tendências para as árvores do clone plantadas nos solos de menor fertilidade (Fazendas Limeira e Tapera Queimada) em relação às árvores do clone plantadas no solo de melhor fertilidade (Fazenda Mendes União): maior densidade básica da madeira e casca; menores altura e teor de massa seca da árvore; maior teor de casca na árvore; menor teor de extrativos totais e maior teor de holocelulose; maior rendimento bruto e depurado da polpação; menor consumo específico de madeira/t de polpa e maiores índices de rasgo e tração em baixos níveis de refino.

Palavras-chave: Fertilidade do solo, propriedades da madeira, polpa Kraft.

\section{INTRODUCTION}

In Brazil, Eucalyptus grandis is one of the most popular species to use as raw material for production of cellulose pulp. Contributing factors to choose this species include its excellent silvicultural characteristics for commercial planting and high yield rates. In addition, it provides excellent delignification, bleaching and papermaking results. In São Paulo state, many stands are planted in soils with limited suitability for food production, particularly with low fertility, but that nonetheless allow mechanization. Thus, rational use of these soils and their potential for reforestation procedures becomes critical.
In Brazil, Eucalyptus grandis Hill ex Maiden is the most commonly cultivated and is proving the best performing species in low fertility soils. However, it has been showing dissimilar development in low fertility soils, suggesting that studies should be carried out to clarify the cause of such pattern and whether desirable wood characteristics for industrial purposes are somehow being altered as a function of these yield dissimilarities. Today, physical and chemical properties have increasingly been taken into account when assessing wood as raw material for technological purposes, in particular the effects of these properties on the delignification process and on final pulp quality.

\footnotetext{
${ }^{1}$ Forest Engineer, Professor Ph.D. in Physical Chemistry - Departamento de Recursos Naturais - Ciências Florestais - Universidade Estadual Paulista/UNESP - Cx. P. 237 - 18603-970 - Botucatu, SP - sansigolo@fca.unesp.br

${ }^{2}$ Forest Engineer - Fibria - 29197-900 - Aracruz, ES - esramos@fibria.com.br
} 
Sandy, low fertility soils cannot be accepted as permanent nutrient reservoirs, since not only are nutrients consumed by forest exploration, they are also subject to erosion and leaching, which ultimately affects local productivity. This trend pattern can be minimized by combining fertilization with forest management practices (COLE, 1981, PRITCHET, 1979). However, soils considered appropriate for forest production such as Entisols and some Oxisols, in tropical conditions are chiefly constituted by minerals in the late weathering stages, which leaves very reduced amounts to still undergo weathering and release nutrients for system replenishment. This assertion is confirmed by Lopez (1983), Moniz (1975), Sanchez (1981) and Vieira (1975), who demonstrated that the weathering process of source material only plays a small part in providing nutrients to these soils.

The effects of fertilization on wood are conditional on the existing growth conditions prior to fertilizer application, and also on the species, on tree genetics, on plant spacing and on local edaphic and climatic conditions (ZOBEL et al., 1961). In a study to investigate the quality of Pinus taeda wood in several sites, Rigatto et al. (2004) found that wood originating from clayish texture, fast growing sites had a tendency toward lower basic density values. Overall, studies investigating the effect of fertilization on chemical composition of wood have shown decreased cellulose and extractives content and increased lignin content, in consequence of increasing cell growth rates from fertilization (SHIMOYAMA; BARRICHELO, 1989). After compiling information about the influence of fertilization on wood chemical properties, Vital (1990) concluded that fertilization led to increased tree vigor which potentially can result in thickerwalled cells, leading to increased concentrations of lignin and extractives and to reduced cellulose content. After analyzing 5 fertilization treatments in Eucalyptus grandis stands, Cromer et al. (1998) concluded that an increased growth rate was associated with increased basic density and also with increased Kraft pulp yield. According to Andrade et al. (1994), soil fertility, which is at times altered by fertilization, can influence wood quality particularly by affecting tree growth rates. According to Shimoyama and Barrichelo (1989), main wood characteristics that can be affected by fertilization include amount of woody tissue in softwoods, basic density, fiber characteristics, chemical composition, and amount of juvenile and mature wood. In such studies, according to Gonçalves et al. (1990), it was noted that physical soil properties were often associated with the production capability of forest sites and, consequently, with the quality of the wood produced.

Basic density is considered one of the most important wood properties owing to its relationship with all others (physical, chemical and anatomical properties) and to final pulp quality. Several authors, including Barrichelo et al. (1983), Foelkel (1974), Shimoyama (1990) and Valente et al. (1992) argue that basic density is a highly complex property in that it results from a combination of anatomical elements and chemical components in wood. In a study with Eucalyptus grandis at age 7 years and Eucalyptus pilularis at age 6 years, Machado et al. (1988) observed that Eucalyptus pilularis had higher basic density than Eucalyptus grandis. As a consequence, Eucalyptus pilularis showed higher tearing resistance, Runkel index, apparent specific volume and opacity, despite lower coefficient of flexibility, tensile strength, bursting strength, and stretch.

Literature emphasizes the importance of wood basic density as the main characteristic influencing not only wood cost and industrial yield but, above all, final pulp and paper quality (FOELKEL et al., 1992; SHIMOYAMA, 1990; WEHR, 1991). The volumetric yield of a digester is strongly associated with basic density. The influence of basic density on volumetric yield (specific wood consumption) is easily understood if one considers that less log and chip handling is required in order to obtain a certain amount of mass (FOELKEL et al., 1992; WEHR, 1991). Foelkel et al. (1992) reported that basic density in Eucalyptus wood can vary from 0.300 to $0.800 \mathrm{~g} / \mathrm{cm}^{3}$, yet the recommended basic density for pulp production is in the range of 0.450 and $0.550 \mathrm{~g} / \mathrm{cm}^{3}$ (FONSECA et al., 1996; WEHR, 1991). Use of low density woods leads to reduced pulp yield, yet denser woods are more difficult to process into chips and impregnate, and they consume large quantities of reagents and may provide low yields and high rejects (WEHR, 1991). Dias and Silva Júnior (1985) studied 25 trees of Eucalyptus grandis at age 7 years from the same origin. Basic density at DBH level was established as the reference basic density. They concluded that yield after delignification reaches its peak when basic density is about $0.470 \mathrm{~g} / \mathrm{cm}^{3}$ and decreases with increasing density.

Observing the work of several authors, it is clearly noticeable that the chemical composition of wood aroused their interest in investigating possible effects of chemical components on final pulp quality and process yield (SANSÍGOLO, 2000). Wood chemical composition plays an important role in connection with Kraft pulp yield.

Cerne, Lavras, v. 17, n. 1, p. 47-60, jan./mar. 2011 
Lignin and extractives, for instance, directly influence alkali consumption, delignification results and industrial production potential (FONSECA et al., 1996). Barrichelo and Brito (1977), studying Eucalyptus grandis trees, found a negative correlation between lignin content and holocellulose content and pulp yield. Using Eucalyptus grandis at age 5 to 10 years, in a total of 25 trees per age, with disks taken at base, at breast height and at $25 \%, 50 \%, 75 \%$ and $100 \%$ of the commercial height, Barrichelo et al. (1983) found that pulp yield is highly correlated with hemicellulose content. A high correlation between hemicellulose and pulp yield was also found by Wehr (1991) in a study with 4 lots of different types of Eucalyptus grandis. The author also found that woods with low concentrations of extractives and lignin are related to improved yield.

The main objective of this work is to assess the quality of wood and pulp from a clone of Eucalyptus grandis planted in three different soils, two of which being low fertility and one being a superior fertility soil. Following this approach, specific objectives included: determining likely differences between the three soils, determining the effects of each soil on wood quality through analysis of basic density and chemical properties, determining the influence of wood quality on the delignification process and on final pulp quality.

\section{MATERIAL AND METHODS}

\subsection{Material}

Experimental material consisted of a clone of Eucalyptus grandis at age 4 years approximately, from three locations (Fazenda Limeira, Fazenda Tapera Queimada and Fazenda Mendes União), which are owned by Lwarcel Celulose e Papel Ltda, in Lençóis Paulista-SP. In Fazenda Limeira and Fazenda Tapera Queimada soils have low fertility, while in Fazenda Mendes União the soil has superior fertility.

\subsection{Methods}

\subsubsection{Sampling and soil analysis}

Soil samples were collected from each location for analysis, from within $0-20 \mathrm{~cm}$ and $20-40 \mathrm{~cm}$ of depth, with the help of an auger. Composite samples were gathered from at least 10 grab samples for each of the three soil types. Analyses were performed at the soil division of the Department of Natural Resources of the Faculty of Agronomic Sciences-UNESP, and included macroelement, microelement, and aluminum and sulfur composition.

\subsubsection{Tree sampling}

Nine trees were removed from each location or soil type ( 1 clone $\mathrm{x} 3$ soil types $\mathrm{x} 9$ trees $=27$ trees). Average DBH was used as criterion for tree selection in each soil type. Trees were felled and measurements were taken of total height, commercial height and DBH with bark. Disks $3 \mathrm{~cm}$ thick were removed at base level, at 25\%, 50\%, 75\% and $100 \%$ of the commercial height (height to a minimum diameter of $8 \mathrm{~cm}$ including bark). For each location or soil type, the nine trees randomly originated 3 composite samples which constituted the experimental replicates. Each sample was composed of 3 trees.

\subsubsection{Wood basic density and dendrometric parameters}

Once disks were removed, measurements were taken of diameter with and without bark. Disks were then cut into four wedges at straight angles. The first wedge was used for basic density determination, the second wedge was used for analysis of wood chemical composition, the third wedge was used for Kraft delignification and the fourth wedge was kept aside. Basic density was determined using the hydrostatic scale method (ASSOCIAÇÃO BRASILEIRA DE NORMAS TÉCNICAS - ABNT, 2003). Average basic density was determined using the basic density of each wedge and respective diameter without bark. The commercial volume with bark or without bark of each tree was determined using the Smalian formula. The percentage of bark, in volume and mass, was determined based on the volumes with bark and without bark of each tree and bark basic density. Commercial dry matter was determined based on average basic density and commercial volume without bark.

\subsubsection{Wood chemical composition}

The composite sample from each location or soil type was obtained by assembling wood sticks manually removed from the disk wedges at different tree heights. The sticks were processed into sawdust using a Wiley mill. The sawdust was then classified to obtain a 40/60 mesh fraction. The following analyses were carried out: total extractives (TAPPI T12 wd-82), Klason lignin (TAPPI T 222 om-98) and holocellulose (100 - \% total extractives \% lignin) (TECHNICAL ASSOCIATION OF THE PULP AND PAPER INDUSTRY - TAPPI, 1999).

Cerne, Lavras, v. 17, n. 1, p. 47-60, jan./mar. 2011 


\subsubsection{Kraft delignification and pulp analysis}

Kraft delignification of composite samples was done in a rotating digester with a 20 liter capacity, and each pulping process consisted of $500 \mathrm{~g}$ of dry wood, under the following conditions: active alkali as $\mathrm{Na}_{2} \mathrm{O}$ on dry wood basis $=14.0 \%$, sulfidity $=18 \%$, anthraquinone on wood dry basis $=0.05 \%$, maximum temperature $=170^{\circ} \mathrm{C}$, heat-up time $=90$ min., time at maximum temperature $=30 \mathrm{~min}$. After delignification and pulp washing, determinations were made of total and screened yields, rejects on pulp and wood basis, specific wood consumption, Kappa number (TAPPI T 236 cm-85), viscosity (TAPPI T230 om-94) and Bauer McNett screening of pulp (TAPPI T233 cm-95).

\subsubsection{Physicomechanical properties of pulps}

The delignified Kraft pulps were refined using a Jokro Mühle centrifugal mill, 150rpm, using $16 \mathrm{~g}$ of sample per beating unit at a concentration of $6 \%$, to 2000, 4000,
6000 and 8000 revolutions. The degree of refining was expressed as Schopper-Riegler degree (SCANDINAVIAN PULP, PAPER AND BOARD-SCAN-C, 1980). Handsheets weighing $60 \mathrm{~g} / \mathrm{m}^{2}$ were made for physicomechanical tests using a Rapid Köthen sheet former and then stored at $50 \pm$ $2 \%$ of RH and $23 \pm 2^{\circ} \mathrm{C}$ of temperature (TAPPI T 402 om93). Physicomechanical properties according to predefined degrees of refining included: apparent specific gravity/ apparent specific volume (TAPPI T 220 sp-96), tear index (TAPPI T 414 om-98), air resistance (TAPPI T 460 om-96) and tensile properties (TAPPI T 494 om 96).

\section{RESULTS AND DISCUSSION}

3.1 Complete chemical analysis of the soil including macroelements, microelements, aluminum and sulfur

Figures 1 to 3 provide soil analysis results for Fazenda Limeira, Fazenda Tapera Queimada and Fazenda Mendes União, following procedures described by Raij et al. (2001).
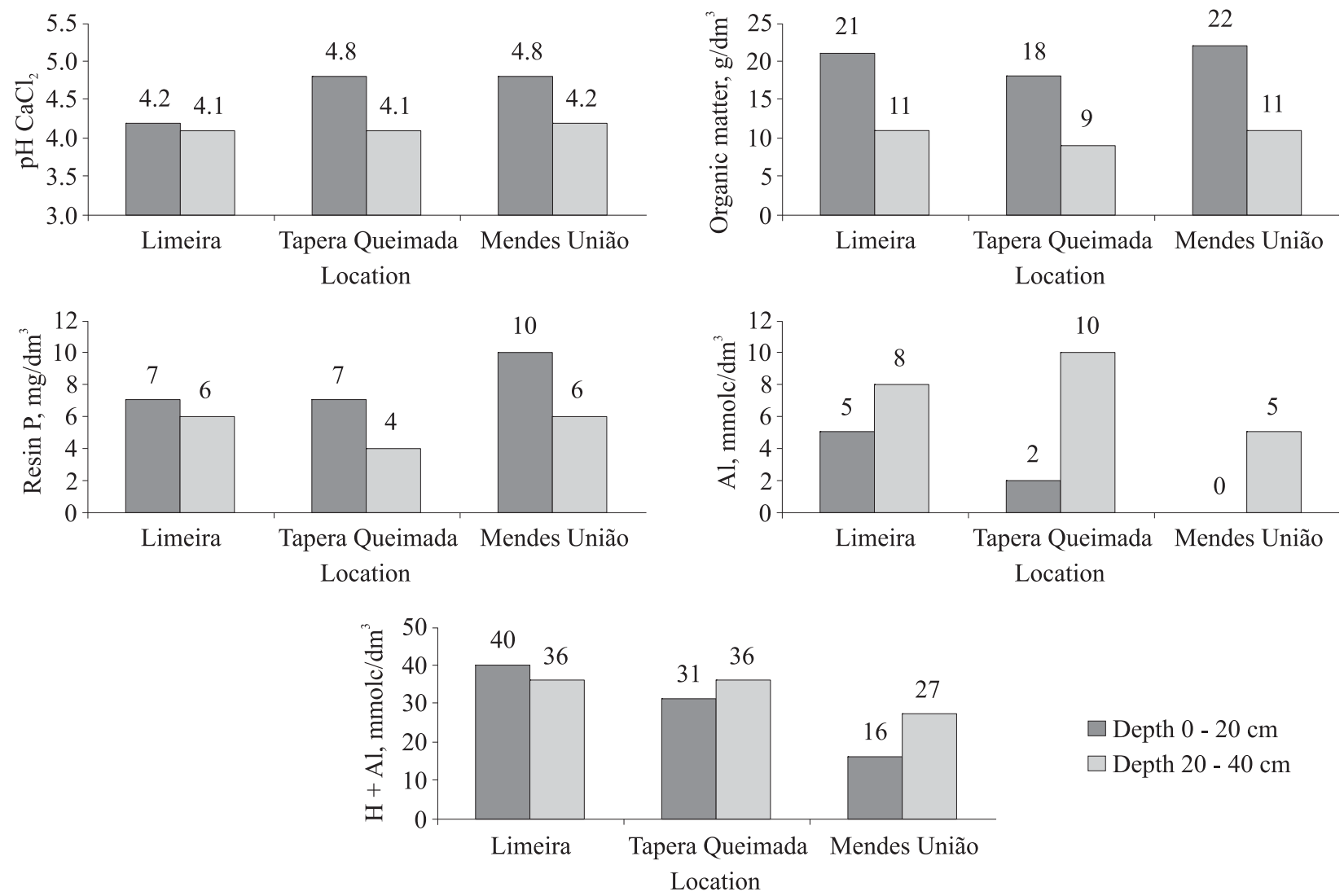

Figure 1 - pH, organic matter, resin P, aluminum and hydrogen plus aluminum in soil of three locations.

Figura 1 - pH, matéria orgânica, P resina, alumínio e hidrogênio mais alumínio nos solos dos três locais.

Cerne, Lavras, v. 17, n. 1, p. 47-60, jan./mar. 2011 

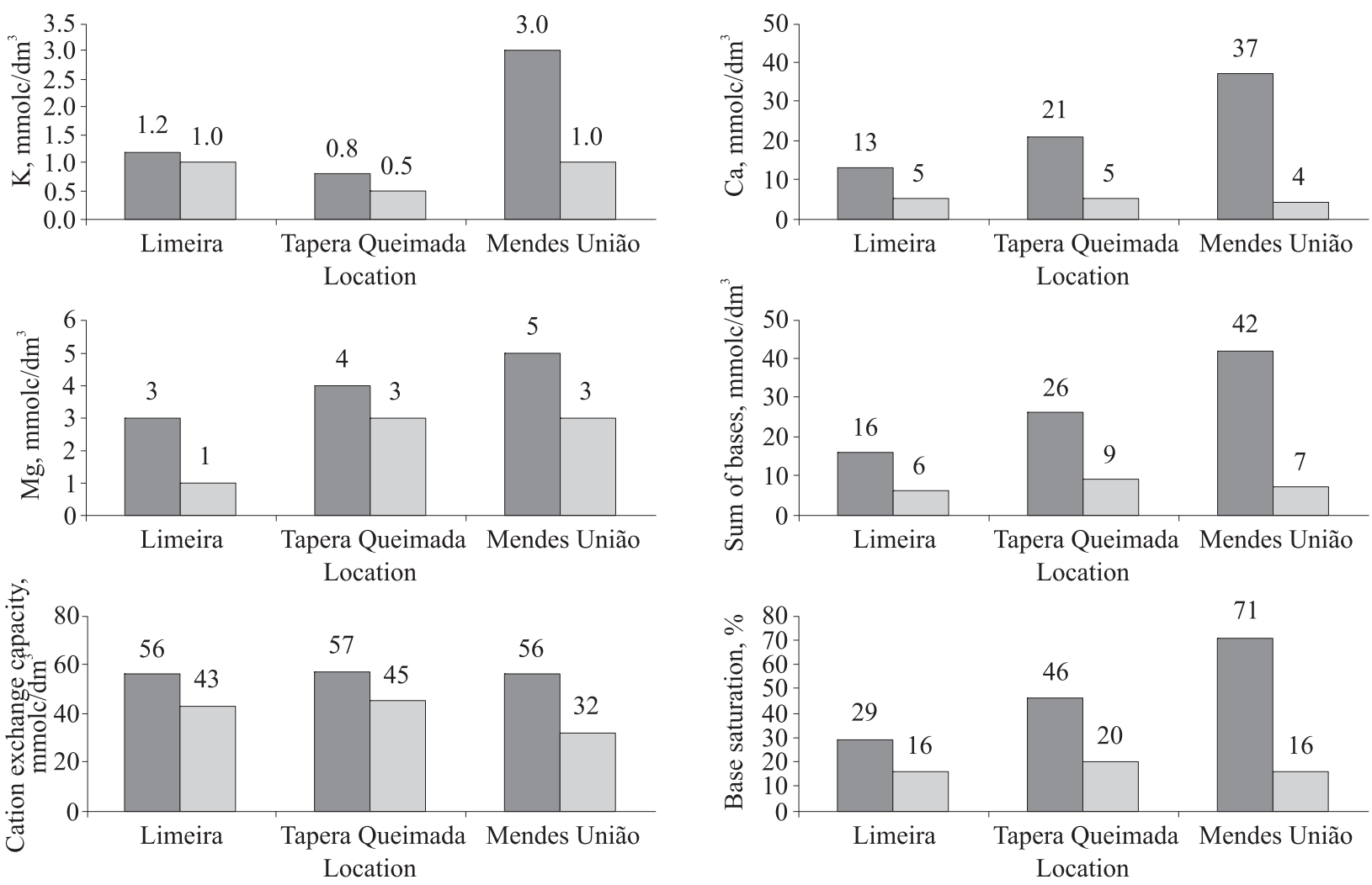

$\square$ Depth $0-20 \mathrm{~cm} \quad \square$ Depth $20-40 \mathrm{~cm}$

Figure 2 - Concentrations of potassium, calcium, magnesium, sum of bases, cation exchange capacity and base saturation in soil of three locations.

Figura 2 - Teores de potássio, cálcio, magnésio, soma de bases, capacidade de troca catiônica e saturação por bases nos solos dos três locais.

As can be observed in Figure 1, $\mathrm{pH}$ in $\mathrm{CaCl}_{2}$ for the three soils was found extremely low according to the interpretation suggested by Raij et al. (2001), who considers $\mathrm{pH}$ values from 5 to be low. According to Raij and Quaggio (1983), $\mathrm{pH}$ in $\mathrm{CaCl}_{2}$ provides better correlations for agricultural purposes. For Fazenda Tapera Queimada and Fazenda Mendes União the $\mathrm{pH}$ did not differ at $0-20 \mathrm{~cm}$ of depth, higher than the value found for Fazenda Limeira. The soils at Fazenda Tapera Queimada and Fazenda Mendes União were thus found slightly less acidic. There was a tendency for $\mathrm{pH}$ value to decrease with growing depths, for the three soils. Organic matter content is useful to provide an idea of soil texture. The three soils showed a medium texture tendency at $0-20 \mathrm{~cm}$ of depth, due to accumulation of organic matter at surface level. At 20-40 $\mathrm{cm}$ of depth, the soils were found to have sandy texture. $\mathrm{P}$ levels within the $0-20 \mathrm{~cm}$ layer were considered average at
Fazenda Limeira and Fazenda Tapera Queimada, reaching higher levels at Fazenda Mendes União according to the interpretation suggested by Raij et al. (2001). As for the 20-40 cm layer, the three soils showed low P levels. The condition of P scarcity is aggravated from the $20 \mathrm{~cm}$ layer, with $\mathrm{P}$ levels decreasing along the soil profiles. Aluminum content was found high in the three soils as depth decreased. Fazenda Tapera Queimada showed $\mathrm{Al}^{3+}$ superiority in greater depths. The pattern of $\mathrm{H}+\mathrm{Al}$ was found higher in Fazenda Limeira and Fazenda Tapera Queimada in comparison to Fazenda Mendes União. Raij et al. (2001) argue that the presence of free $\mathrm{H}$ (active acidity) is insubstantial from the viewpoint of ion exchange for fertility purposes and also that the $\mathrm{H}$ corresponding to potential acidity $(\mathrm{H}+\mathrm{Al})$ does not participate in exchange reactions, and so exchange positions start to be occupied predominantly by exchangeable $\mathrm{Al}$. 

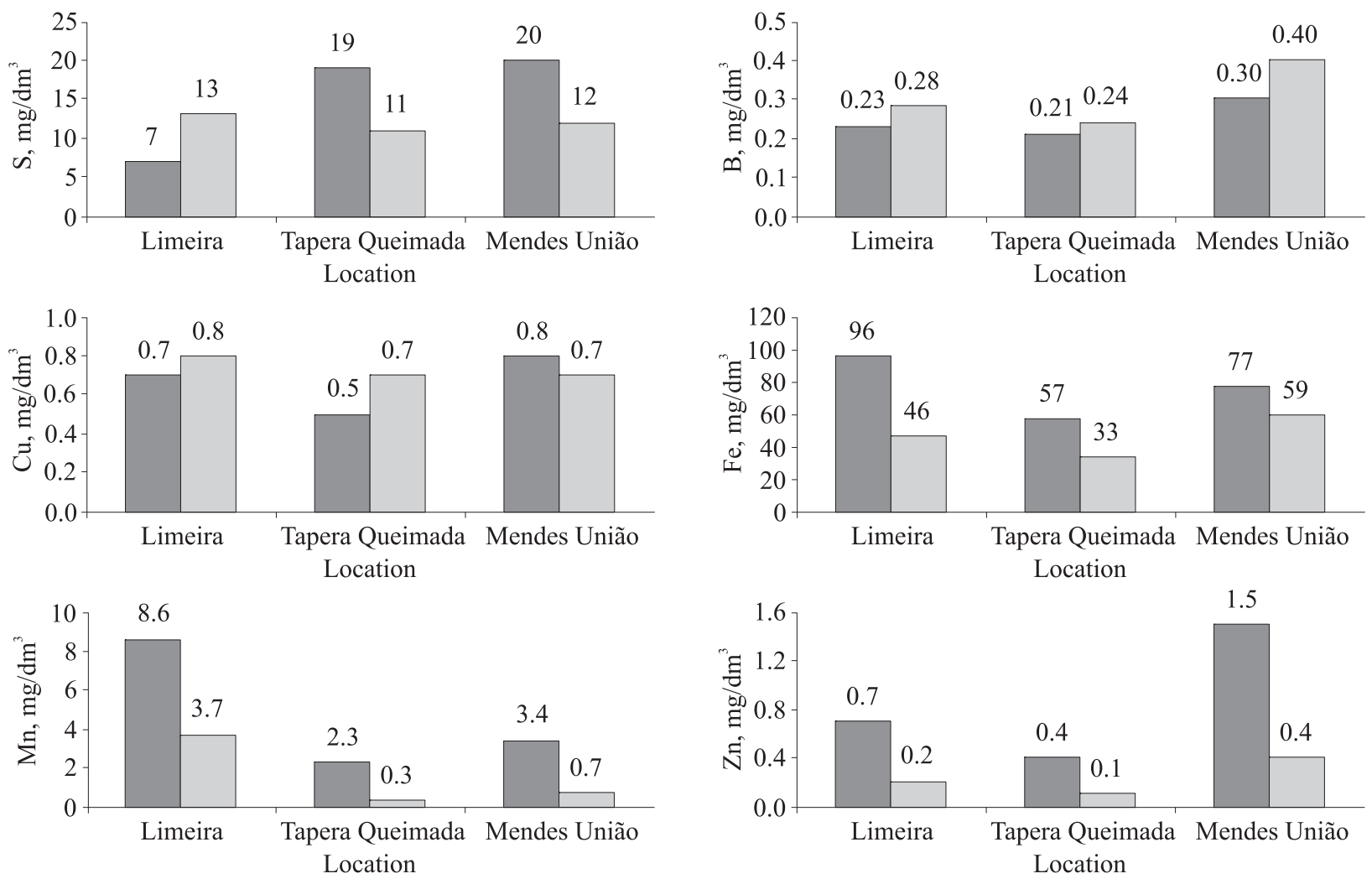

Figure 3 - Sulfur, boron, copper, iron, manganese and zinc contents in soil of three locations.

Figura 3 - Teores de enxofre, boro, cobre, ferro, manganês e zinco nos solos dos três locais.

Figure 2 shows that potassium content is very low for Fazenda Tapera Queimada, low for Fazenda Limeira and average for Fazenda Mendes União at 0-20 cm of depth, decreasing with greater depth. Calcium content was found high for all three soils at 0-20 cm of depth, particularly at Fazenda Mendes União, decreasing with greater depths. Magnesium content was found low for Fazenda Limeira and Fazenda Tapera Queimada and average for Fazenda Mendes União, decreasing slightly with greater depths. The sum of bases was found lower in soil of Fazenda Limeira, particularly at 20-40 cm of depth. Literature mentions that exchangeable bases of the soil are extracted and exported to larger degrees in Eucalyptus cultures (BELLOTE, 1979). Cation exchange capacity showed a decreasing tendency as a function of increasing depths, for all three soils. The soil of Fazenda Mendes União showed a higher base saturation index.

Figure 3 shows that the soil of Fazenda Mendes União has higher sulfur content than Fazenda Limeira and
Fazenda Tapera Queimada. As for micronutrients, boron and copper contents were found average in the three soils, whereas iron content was found high in the three soils, decreasing with greater depths. The manganese content only showed one high value (Fazenda Limeira), the remaining values being average. Zinc content was found average for Fazenda Limeira, low for Fazenda Tapera Queimada and high for Fazenda Mendes União within the 0-20 cm layer. Zinc contents were found low within the $20-40 \mathrm{~cm}$ layer.

It is very likely that wood from each of the three locations have distinct iron, manganese and copper contents since the concentrations of these elements in each soil differ. For instance, iron and manganese content at Fazenda Limeira were found well above that of the other two soils (Figure 3). These metals, being present in wood in high concentrations, exert great influence on bleaching processes, especially those using hydrogen peroxide and/or oxygen (BASTA et al., 1991; LJUNGGREN; JOHANSSON, 1994; MCCLOSKEY et al., 1975),

Cerne, Lavras, v. 17, n. 1, p. 47-60, jan./mar. 2011 
as they catalyze the decomposition of the bleaching agent. The main source of metals in pulp is the wood. It is estimated that this raw material contributes about $95 \%$ of metallic ions total. The remaining $5 \%$ can be attributed to other sources such as industrial water, assisting chemicals and corrosion of equipment.

\subsection{Basic density and dendrometric results at each location}

Figure 4 provides dendrometric and basic density results. As can be observed, basic density values found for Fazenda Limeira and Fazenda Tapera Queimada were nearly the same. A tendency was noted for wood from Fazenda Mendes União (more fertile soil) to have lower basic density than wood from Fazenda Limeira and Fazenda Tapera Queimada (less fertile soils), though differences were not significant. Bark basic density in Fazenda Mendes União was found significantly lower. Brasil and Ferreira (1971), analyzing the behavior of Eucalyptus species at age 5 years commonly planted in São Paulo state, concluded that in regions with more fertile soils and high yielding stands, wood basic density is lower. A similar pattern was observed by Shimoyama and Barrichelo (1989), when tree response to fertilization was a decrease in wood basic density, in consequence of increased percentage of juvenile wood.
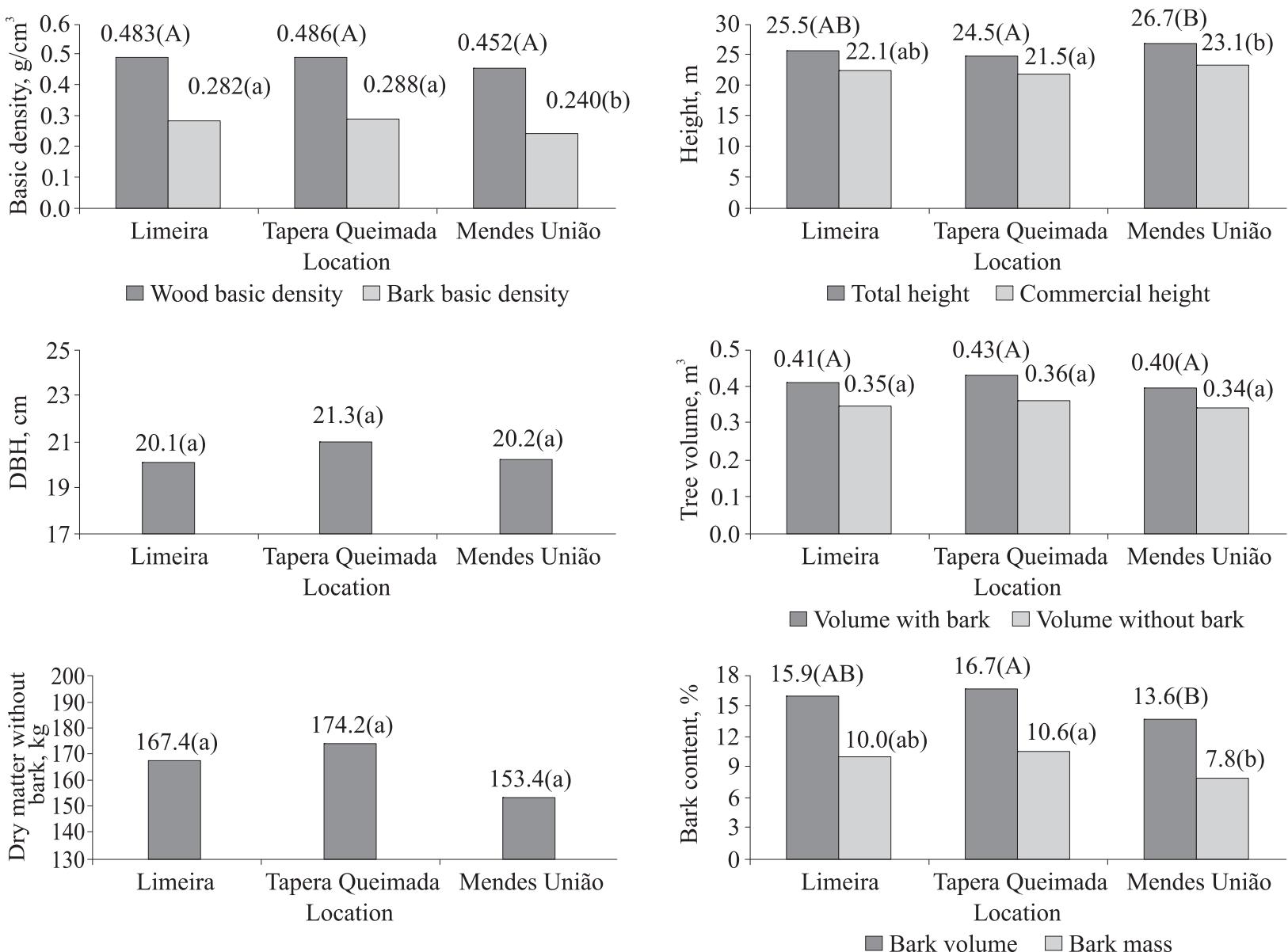

Figure 4 - Basic density, total and commercial height, DBH, volume with and without bark, tree dry matter, bark volume and bark mass in the three locations. Same letters for a parameter reveal no significant differences by the Tukey test at the $5 \%$ significance level.

Figura 4 - Densidade básica, alturas total e comercial, DAP, volumes com casca e sem casca, massa seca da árvore, teor de casca em volume e massa nos três locais. Letras iguais em determinado parâmetro não mostram diferenças significativas pelo teste de Tukey a 5\% de significância.

Cerne, Lavras, v. 17, n. 1, p. 47-60, jan./mar. 2011 
Studies to investigate woods from clonal stands of Eucalyptus operated by leading Brazilian companies demonstrated that $40 \%$ of woods showed basic density values above $0.500 \mathrm{~g} / \mathrm{cm}^{3}$, with the majority presenting values between 0.465 and $0.490 \mathrm{~g} / \mathrm{cm}^{3}$ (GOMIDE et al. 2005). According to these authors, this indicates that companies have favored densities in the range of 0.500 $\mathrm{g} / \mathrm{cm}^{3}$, tending slightly to less. Total and commercial tree heights in Fazenda Mendes União (more fertile soil) were found greater than in Fazenda Tapera Queimada and equal to heights in Fazenda Limeira, as was illustrated by statistical analyses. DBH and volumes with and without bark were nearly the same for the three locations. A tendency was noted for lower tree dry matter content in Fazenda Mendes União. Significant differences were found in bark content, in volume and mass, depending on whether soils are more or less fertile. Bark content was found lower in more fertile soil (Fazenda Mendes União).

\subsection{Chemical composition of wood from each location}

Figure 5 provides the chemical composition of wood from each of the three locations. No significant differences were found in the relevant chemical parameters (total extractives, lignin and holocellulose). Only a tendency was noted for wood from Fazenda Mendes União (more fertile soil) to show a higher total extractives content and a lower holocellulose content in comparison to wood from Fazenda Limeira and Fazenda Tapera Queimada (less fertile soils). Higher total extractives contents have a negative influence on pulping yield, since they consume reagents and are usually removed during delignification.

\subsection{Pulping yield and pulp analysis of each location}

Figure 6 provides pulping yield and analysis of pulp from each of the three locations. As can be observed, woods from Fazenda Limeira and Fazenda Tapera Queimada (less fertile soils) gave higher total and screened yields of cellulose pulp, and statistically similar. Wood from Fazenda Mendes União (more fertile soil), on the other hand, gave significantly lower total and screened yields. There, the pulping processes were repeated and indeed confirmed a low screened yield, even with a lower active alkali charge. A possible explanation for this result is the higher extractives contents and lower holocellulose contents in this wood, as well as slightly lower basic density (Figure 5). Brazilian pulp companies have set $50 \%$ as lower threshold of gravimetric pulping yield (GOMIDE et al., 2005). Pulp rejects were found slightly higher for Fazenda Tapera Queimada, average for Fazenda Limeira and lower for Fazenda Mendes União. Kappa number was found similar for the three locations and very close to 20 under similar pulping conditions.
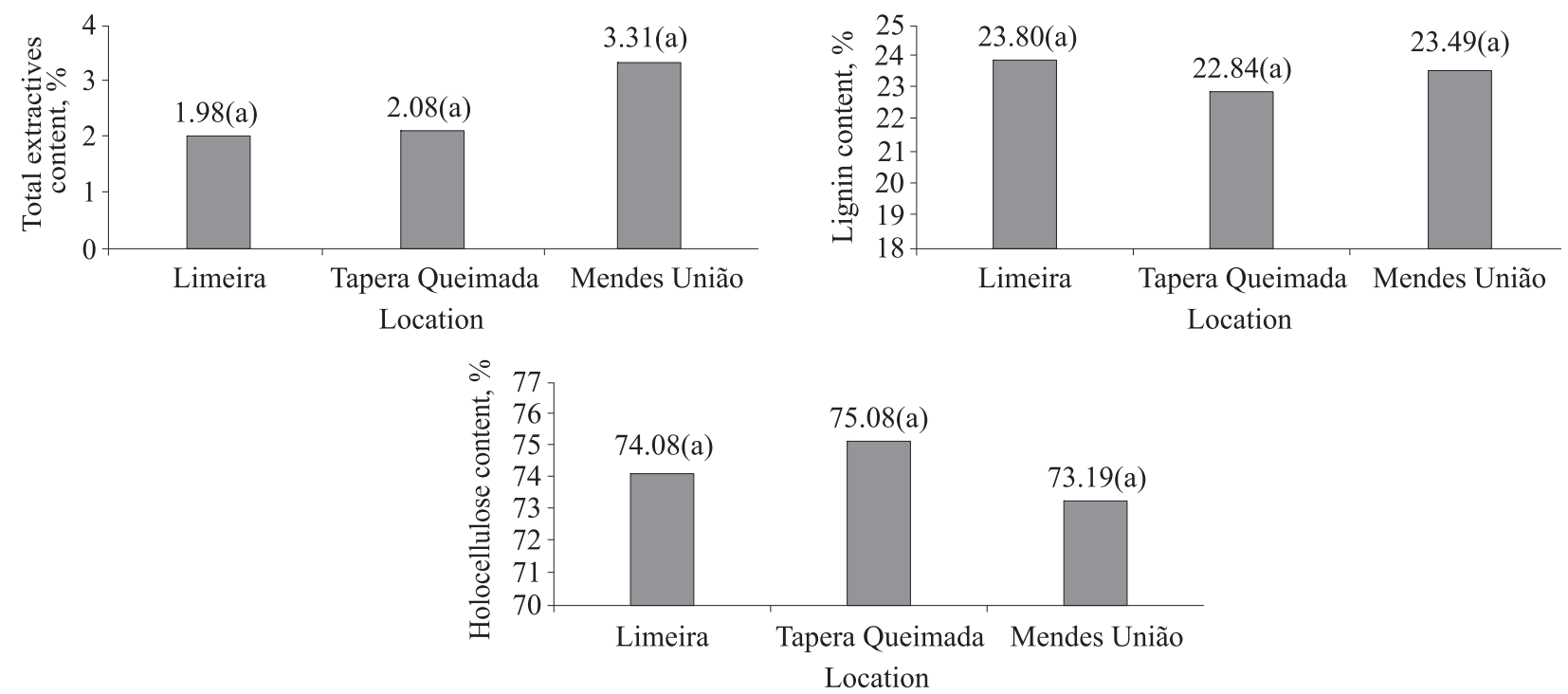

Figure 5 - Total extractives, lignin and holocellulose contents in wood from the three locations. Same letters for a parameter reveal no significant differences by the Tukey test at the $5 \%$ significance level.

Figura 5 - Teores de extrativos totais, lignina e holocelulose nas madeiras dos três locais. Letras iguais em determinado parâmetro não mostram diferenças significativas pelo teste Tukey a 5\% de significância.

Cerne, Lavras, v. 17, n. 1, p. 47-60, jan./mar. 2011 

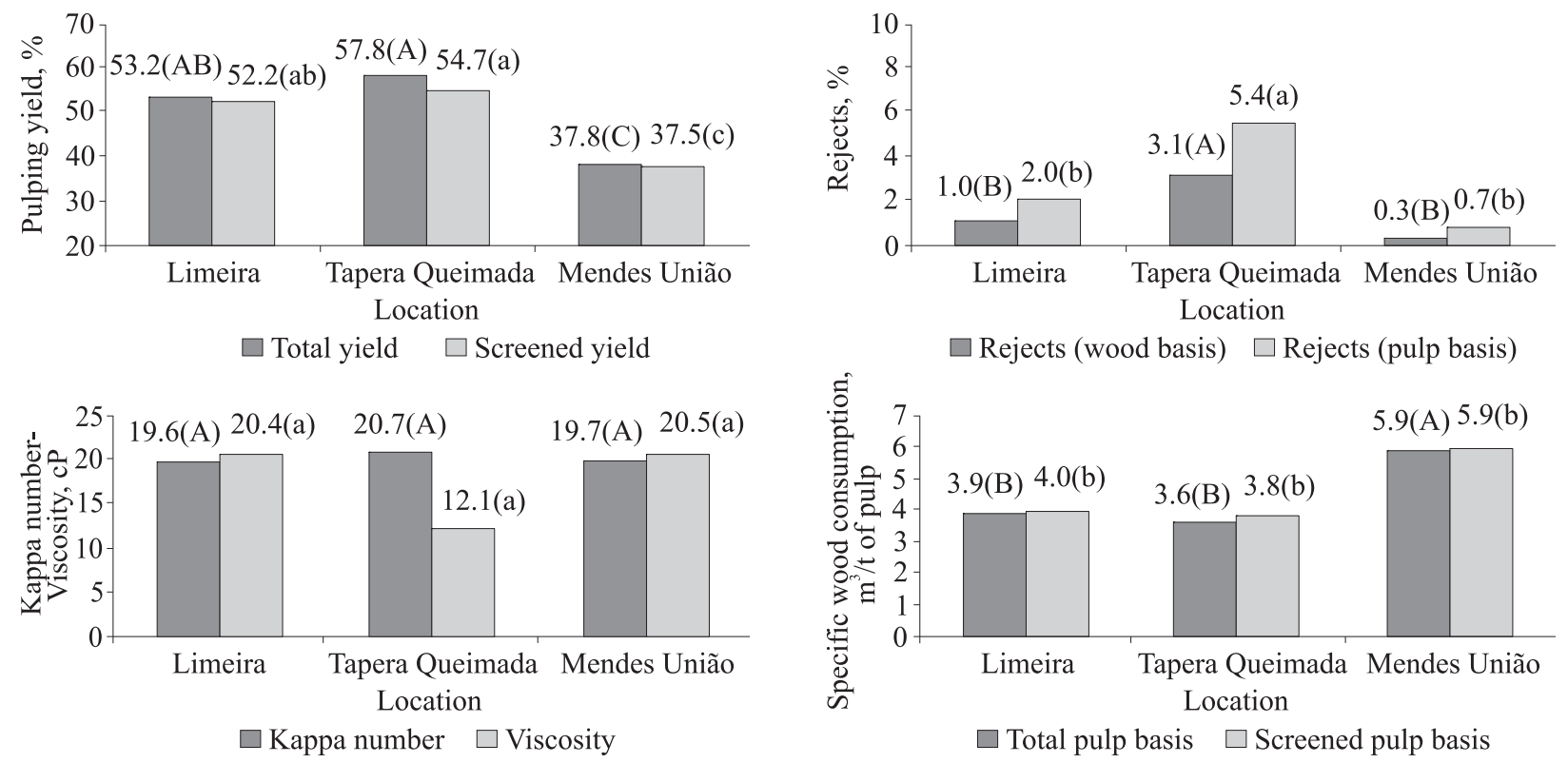

$\square$ Kappa number $\square$ Viscosity

$\square$ Total pulp basis $\square$ Screened pulp basis

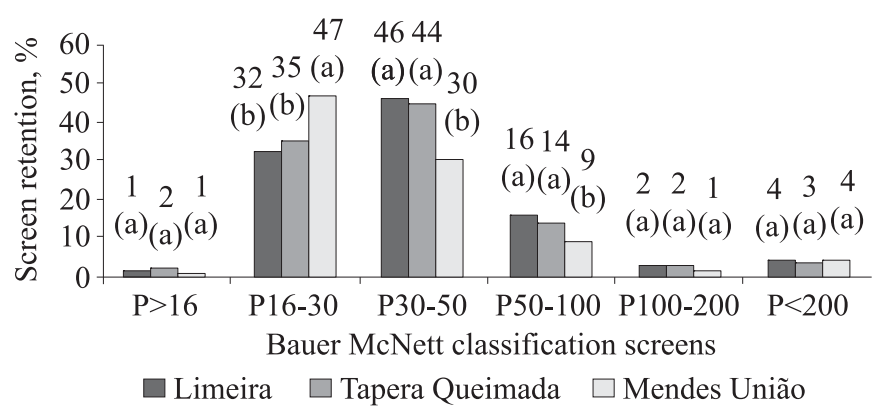

Figure 6 - Yields, rejects, Kappa number, viscosity, specific wood consumption and Bauer McNett screen classification of pulps at the three locations. Same letters for a parameter reveal no significant differences by the Tukey test at the $5 \%$ significance level.

Figura 6 - Rendimentos, teores de rejeito, número kappa, viscosidade, consumo especifico de madeira e classificação em Bauer McNett das polpas dos três locais. Letras iguais em determinado parâmetro não mostram diferenças significativas pelo teste de Tukey a 5\% de significância.

As seen previously, lignin content in wood was also very similar in the three locations (Figure 5). Therefore, the lignin content in wood and the residual lignin content of the pulp (Kappa number) were not influenced by soil type. Viscosity did not differ significantly between locations, despite reduced for Fazenda Tapera Queimada. Specific wood consumption to produce a ton of total or screened pulp was similar in Fazenda Limeira and Fazenda Tapera Queimada (less fertile soils) and higher in Fazenda Mendes União (more fertile soil). The higher specific wood consumption for Fazenda Mendes União is due to lower wood basic density there and to lower pulping yields. Figure 6 also provides screen classification of unbleached fibers using a Bauer McNett classifier. As can be observed, screen retentions were very similar for pulps from Fazenda Limeira and Fazenda Tapera Queimada (less fertile soils), differing from pulp from Fazenda Mendes União (more fertile soil). The sum of fiber retentions on screens 16-30 and 30-50 mesh (longer fibers) reveals values of $77.6 \%$ (Fazenda Limeira), 79.1\% (Fazenda Tapera Queimada) and 76.9\% (Fazenda Mendes União), showing a slight tendency toward longer fibers in pulp of less fertile soils. It is also very likely that pulp fibers of less fertile soils have thicker walls, since the wood in these soils showed higher basic density. These morphological differences in fibers influenced the physicomechanical properties of pulp. 


\subsection{Pulp physicomechanical properties in each location}

Figures 7 and 8 provide physicomechanical properties of pulp for each of the three locations. As can be observed in Figure 7, Schopper Riegler degrees were statistically similar to a number of revolutions for pulps of all three locations. At a higher number of revolutions (6000 and 8000) there was a tendency for pulp from Fazenda Mendes União to refine more rapidly due to the presence of more flexible fibers in that wood (lower basic density). Increases in degree of refining as a function of number of revolutions was low, for all three locations, and can be attributed to the juvenile nature of these fibers, from wood at age four years. According to Trugilho et al. (1996), juvenile eucalyptus wood has shorter length fibers and vases, smaller cell diameter, thinner cell walls, a higher ratio of fibers and a lower ratio of vases. There was a tendency for handsheets from Fazenda Mendes União to provide slightly higher values of apparent specific gravity (or slightly lower values of apparent specify volume) due to the lower basic density of that wood. The progress of apparent specific gravity as a function of rising degrees of refining was low and decreased with SR degree of 28,3 to 31,3 . This behavior was observed in all three locations and is uncommon when compared to other pulps at commercial age. There was a tendency toward a lower tear index for pulp from Fazenda Mendes União, especially at a lower number of revolutions (2000 and 4000). Tearing resistance depends at least on three factors: fiber length, fiber strength and degree of interfiber bonding. As seen previously, the pulp of Fazenda Mendes União was found to have more flexible fibers (lower basic density) and a tendency toward
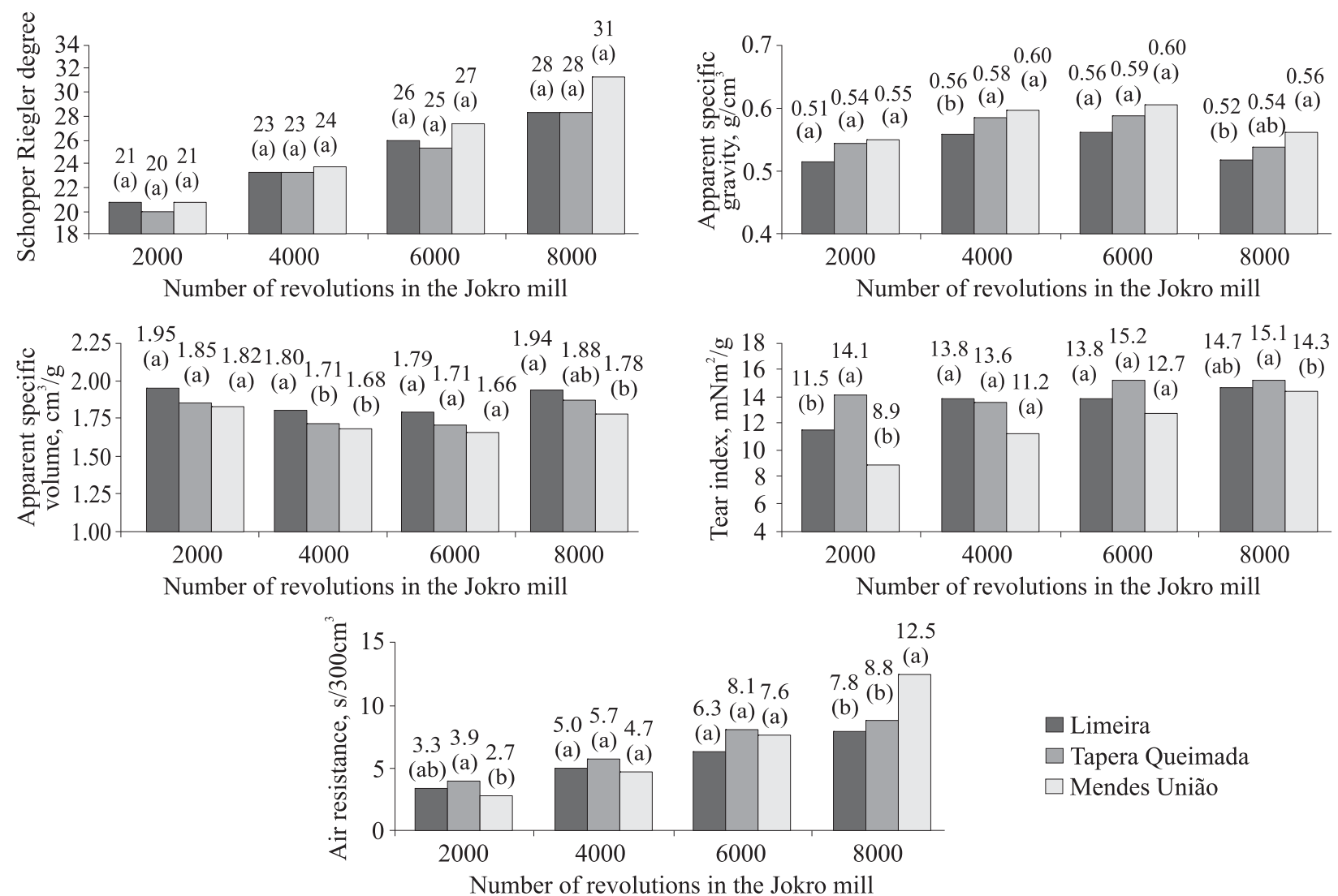

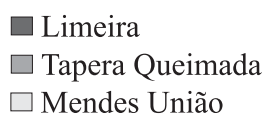

$\square$ Mendes União

Number of revolutions in the Jokro mill

Figure 7 - Schopper Riegler degree, apparent specific gravity, apparent specific volume, tear index and air resistance of pulp from each location. Same letters for a parameter reveal no significant differences by the Tukey test at the $5 \%$ significance level.

Figura 7 - Grau Schopper Riegler, peso específico aparente, volume específico aparente, índice de rasgo e resistência ao ar das polpas dos três locais. Letras iguais em determinado parâmetro não mostram diferenças significativas pelo teste de Tukey a 5\% de significância.

Cerne, Lavras, v. 17, n. 1, p. 47-60, jan./mar. 2011 

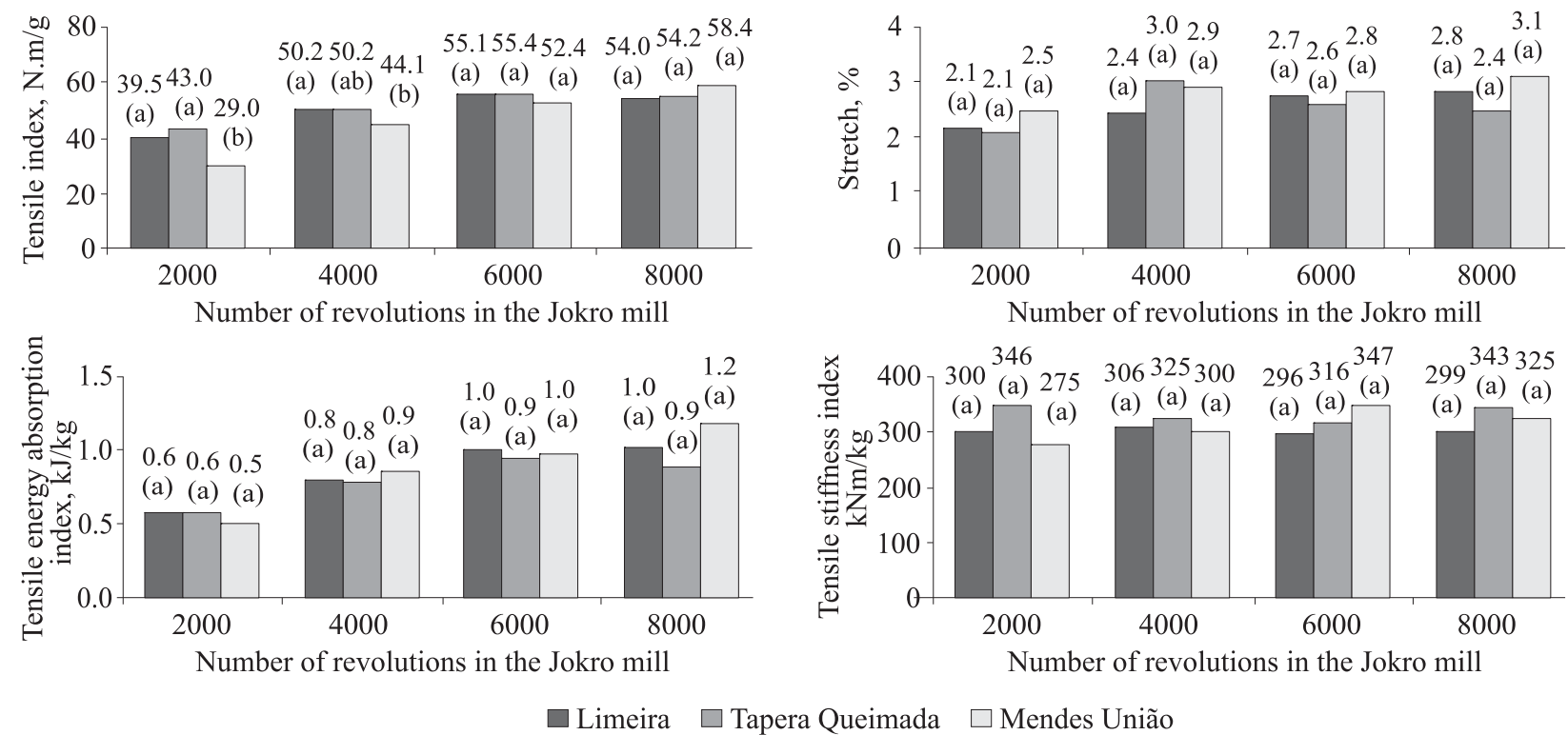

Figure 8 - Tensile index, stretch, tensile energy absorption index and tensile stiffness index of pulps from the three locations. Same letters for a parameter reveal no significant differences by the Tukey test at the $5 \%$ significance level.

Figura 8 - Índice de tração, alongamento, índice de energia absorvida na tração e índice de rigidez na tração das polpas dos três locais. Letras iguais em determinado parâmetro não mostram diferenças significativas pelo teste de Tukey a 5\% de significância.

shorter length fibers according to Bauer McNett screen classification, which justifies these results. Air resistance was similar at several number of revolutions for pulps from all three locations, except 8000 revolutions. At this level, the pulp of Fazenda Mendes União provided a higher value due to greater ease in refining and to the presence of more flexible fibers. Air resistance of paper can be used as an indirect indicator of fluid permeability in the $\mathrm{Z}$ direction of the sheet, also providing information about degree of refining, absorption, apparent specific gravity and filtering.

Figure 8 provides tensile properties of pulps from Fazenda Limeira, Fazenda Tapera Queimada and Fazenda Mendes União. Tensile properties are most critical in determining cellulose pulp strength. There was a tendency toward a lower tensile index for pulp from Fazenda Mendes União, particularly at a lower number of revolutions (2000 and 4000), attributable to the slightly shorter fiber length observed from Bauer McNett classification. The behavior of these cellulose fibers is very different from other fibers at commercial age and are attributable to the juvenile nature of these fibers. The tensile index rose very little with increasing degrees of refining and started to decrease at peak revolution level. In addition, values found at these SR degrees are low if compared to most fibers at commercial age.
These pulps failed to reach a $70 \mathrm{~N}$.m/g tensile index, which is found to be the standard for many end uses of eucalyptus pulp (COTTERILL; MACRAE, 1997). Other tensile properties did not undergo significant changes as a function of soil type.

\section{CONCLUSIONS}

Chemical analyses of soils pointed to lower fertility in Fazenda Limeira and in Fazenda Tapera Queimada and to higher fertility in Fazenda Mendes União.

The basic densities of wood and bark from Fazenda Limeira and from Fazenda Tapera Queimada (less fertile soils) were higher in comparison to values in Fazenda Mendes União (more fertile soil), though differences were not significant.

Trees at Fazenda Limeira and at Fazenda Tapera Queimada showed slightly lower total and commercial heights, and higher bark and dry matter contents in comparison to Fazenda Mendes União.

Woods from Fazenda Limeira and from Fazenda Tapera Queimada (less fertile soils) showed lower total extractives content and higher holocellulose contents in comparison to wood from Fazenda Mendes União (more fertile soil). Lignin content was similar for all three locations.

Cerne, Lavras, v. 17, n. 1, p. 47-60, jan./mar. 2011 
Woods from Fazenda Limeira and from Fazenda Tapera Queimada provided higher total and screened yields, with slightly higher rejects and lower specific wood consumption/t of pulp in comparison to wood from Fazenda Mendes União. Kappa number and viscosity were similar for all three locations.

The Bauer McNett screen classification of pulp fibers showed slightly longer fiber length in pulps from Fazenda Limeira and Fazenda Tapera Queimada.

Pulps from all three locations behaved similarly during the refining process at various revolution levels. Increases in degree of refining as a function of number of revolutions was low for all three locations.

Pulp handsheets from Fazenda Mendes União provided lower tear index and tensile index values at a low number of revolutions (2000 - 4000). Other properties being assessed were found similar.

\section{ACKNOWLEDGMENTS}

The authors wish to thank the Research Aid Foundation of São Paulo State (FAPESP) and Indústria Lwarcel Celulose e Papel S.A.

\section{REFERÊNCIAS}

ANDRADE, A .M. de; VITAL, B. R.; BARROS, N. F. de; DELLA LUCIA, R. M.; CAMPOS, J. C. C.; VALENTE, D. F. Efeitos da fertilização mineral e da calagem do solo na produção e na qualidade da madeira de eucalipto. Revista Árvore, Viçosa, v. 18, n. 1, p. 69-78, 1994.

\section{ASSOCIAÇÃO BRASILEIRA DE NORMAS TÉCNICAS.}

NBR 11941: madeira: determinação da densidade básica. Rio de Janeiro, 2003. 6 p.

BARRICHELO, L. E. G.; BRITO, J. O.; COUTO, H. T. Z.; CAMPINHOS JUNIOR, E. Densidade básica, teor de holocelulose e rendimento em celulose de madeiras de Eucalyptus grandis. Silvicultura, São Paulo, v. 8, n. 32, p. 802-808, set. 1983.

BARRICHELO, L. E. G.; BRITO, J. O. Variações das características da madeira de Eucalyptus grandis e suas correlações com a produção de celulose. In: CONGRESSO ANUAL DA ABTCP, 10., 1997, São Paulo. Anais... São Paulo: ABTCP, 1977. p. 41-46.

BASTA, J.; HOLTINGER, L.; HOOK, J. Controlling the profile of metals in pulp before hydrogen peroxide treatment. In: INTERNATIONAL SYMPOSIUM WOOD AND PULPING CHEM, 6., 1991, Washington. Anais... Washingon: TAPPI, 1991. p. 237-244.

BELLOTE, A. F. J. Concentração, acúmulo e exportação de nutrientes pelo Eucalyptus grandis em função da idade. 1979. 129 f. Dissertação (Mestrado em Engenharia Florestal) Escola Superior de Agricultura “Luiz de Queiroz”, Piracicaba, 1979.

BRASIL, M. A. M.; FERREIRA, M. Variação da densidade básica da madeira de Eucalyptus saligna Sm., E. Alba Reinw e E. grandis Hill ex Maiden aos 5 anos de idade, em função do local e espaçamento. IPEF, Piracicaba, v. 2, n. 3, p. 129-149, 1971.

COLE, D. W. Nutrient cycling in world forest. In: IUFRO WORLD CONGRESS, 17., 1981, Ibaraki. Anais... Ibaraki, 1981. p. 139-160.

COTTERILL, P.; MACRAE, S. Improving eucalyptus pulp and paper quality using genetic selection and good organization. TAPPI Journal, v. 80, n. 6, p. 82-89, 1997.

CROMER, R. N.; BALODIS, V.; CAMERON, D.; GARLAND, C. P.; RANCE, S.; RYAN, P. Eucalyptus grandis fertilizer trials: growth, wood properties and kraft pulp yield. Appita Journal, v. 51, n. 1, p. 45-49, Jan. 1998.

DIAS, R. L. V.; SILVA JUNIOR, C. E. A influência da densidade básica da madeira de híbridos de Eucalyptus grandis em suas características químicas e propriedades de polpação e do papel. In: CONGRESSO ANUAL DA ABTCP, 18., 1985, São Paulo. Anais... São Paulo: ABTCP, 1985. p. 31-55.

FOELKEL, C. E. B. Rendimentos em celulose sulfato de Eucalyptus sp em função do grau de deslignificação e da densidade da madeira. IPEF, Piracicaba, v. 9, p. 61-77, dez. 1974.

FOELKEL, C. E. B.; MORA, E.; MENOCHELLI, S. Densidade básica: sua verdadeira utilidade como índice de qualidade da madeira de eucalipto para a produção de celulose. O papel, São Paulo, v. 53, n. 5, p. 35-40, 1992.

FONSECA, S. M.; OLIVEIRA, R. C.; SILVEIRA, P. N. Seleção da árvore industrial. Revista Árvore, Viçosa, v. 20, n. 1, p. 69-85, jan. 1996. 
GOMIDE, J. L.; COLODETTE, J. L.; OLIVEIRA, R. C. de; SILVA, C. M. Caracterização tecnológica, para produção de celulose, da nova geração de clones Eucalyptus no Brasil. Revista Árvore, Viçosa, v. 29, n. 1, p. 129-137, jan./fev. 2005.

GONÇALVES, J. L. M.; DEMATTÊ, J. L. I.; COUTO, H. T. Z. Relações entre produtividade de sítios florestais de Eucalyptus grandis e E. saligna com propriedades de alguns solos de textura arenosa e média no Estado de São Paulo. IPEF, Piracicaba, n. 43/44, p. 24-39, 1990.

LJUNGGREN, S.; JOHANSSON, E. The kinetics of lignin reactions during oxygen bleaching: 4., the reactivities of different lignin model compounds and the influence of metalions on the rate of degradation. Journal Wood Chemical Technology, v. 14, n. 4, p. 507-525, 1994.

LOPES, A. S. Solos sob “cerrado”: características, propriedades e manejo. Piracicaba: Instituto da Potassa e Fosfato, 1983. $162 \mathrm{p}$.

MACHADO, F. J. J.; GOMIDE, J. L.; CAMPOS, W. O.; CAPITANI, L. R. Caracterização da madeira de Eucalyptus pilularis e estudos para a produção de celulose Kraft. Revista Árvore, v. 12, n. 2, p. 111-122, 1988.

MCCLOSKEY, J. T.; NKEY, J. D.; OMPSON, N. S. Catalytic influence of iron and magnesium-ions in oxygen bleaching reactions. TAPPI, v. 58, n. 2, p. 56-59, 1975.

MONIZ, A. C. Decomposição de rochas e formação de minerais de argila. In: . Elementos de pedologia. Rio de Janeiro: LTC, 1975. p. 305-323.

PRITCHETT, W. L. Properties and management of forest soils. New York: J. Wiley, 1979. 500 p.

RAIJ, B. van; ANDRADE, J. C.; CANTARELLA, H.; QUAGGIO, J. A. Análise química para avaliação da fertilidade de solos tropicais. Campinas: Instituto Agronômico, 2001. 285 p.

RAIJ, B. van; QUAGGIO, J. A. Métodos de análise de solos para fins de fertilidade. Campinas: Instituto Agronômico, 1983. $32 \mathrm{p}$.

RIGATTO, P. A.; DEDECEK, R. A.; MATOS, J. L. M. de. Influência dos atributos do solo sobre a qualidade da madeira de Pinus taeda para produção de celulose Kraft. Revista Árvore, Viçosa, v. 28, n. 2, p. 267-273, mar./abr. 2004.

SANCHEZ, P. A. Suelos del Trópico: características y manejo. San José: IICA, 1981. 660 p.

SANSÍGOLO, C. A. Seleção de árvores matrizes para a produção de polpa Kraft - AQ. 2000. 157 p. Tese (Livre Docência) - Faculdade de Ciências Agronômicas, Universidade Estadual Paulista, Botucatu, 2000.

SCANDINAVIAN PULP, PAPER AND BOARD. SCAN-C 19:65: drainability by the schopper riegler method. Stockholm, 1980.

SHIMOYAMA, V. R. S. Variações da densidade básica e características anatômicas e químicas da madeira de Eucalyptus ssp. 1990. 101 f. Dissertação (Mestrado) - Escola superior de Agricultura "Luiz de Queiroz”, Piracicaba, 1990.

SHIMOYAMA, V. R. S.; BARRICHELO, L. E. G. Importância da adubação na qualidade da madeira e celulose. In: SIMPÓSIO SOBRE ADUBAÇÃO E QUALIDADE DE PRODUTOS AGRÍCOLAS, 1., 1989, Ilha Solteira. Anais... Ilha Solteira: UNESP, 1989. p. 6176.

\section{TECHNICAL ASSOCIATION OF THE PULP AND} PAPER INDUSTRY. TAPPI T 12 wd-82: acid-insoluble lignin in wood and pulp; TAPPI T 222 om-98: kappa number of pulp; TAPPI T236 cm-85: viscosity of pulp: capillary viscometer method; TAPPI T233 cm-95: standard conditioning and atmospheres for paper, board, pulp handsheets, and related products; TAPPI T 402 om-03: physical testing of pulp handsheets; TAPPI T 220 sp96: tensile breaking properties of paper and paperboard; TAPPI T230 om-94: fiber length of pulp by classification; TAPPI T 494 om-96: internal tearing resistance of paper: elmendorf-type method; TAPPI T 414 om-98: air resistance of paper: gurley method; TAPPI T 460 om-96. Atlanta, 1999.

TRUGILHO, F. P.; LIMA, J. T.; MENDES, L. M. Influência da idade nas características físico-mecânicas e anatômicas da madeira de Eucalyptus saligna. Cerne, Lavras, v. 2, n. 1, p. 94-111, 1996.

Cerne, Lavras, v. 17, n. 1, p. 47-60, jan./mar. 2011 
VALENTE, C. A.; SOUSA, A. P. M.; FURTADO, F. P.; CARVALHO, A. P. Improvement program for Eucalyptus globulus at Portucel: technological component. Appita, v. 45, n. 6, p. 403-407, Nov. 1992.

VIEIRA, L. S. Manual da ciência do solo. São Paulo: Agronômica Ceres, 1975. 464 p.

VITAL, B. R. Reflexos da fertilização mineral na qualidade da madeira e na utilização da madeira. In: BARROS, N. F.; NOVAIS, R. F. Relação solo-eucalipto. Viçosa, MG: Folha de Viçosa, 1990. p. 127-186.
WEHR, T. R. Variações nas características de Eucalyptus grandis W. Hill ex- Maiden e suas influências na qualidade de cavacos em cozimentos Kraft. 1991. $84 \mathrm{f}$. Dissertação (Mestrado em Ciências Florestais) - Escola superior de Agricultura “Luiz de Queiroz”, Piracicaba, 1991.

ZOBEL, B. J.; THORBJORSEN, E.; HENSON, F. Geographic, site and individual tree variation in wood properties of loblolly pine. Silvae Genetica, Frankfurt, v. 9, n. 7, p. 149-158, 1961. 